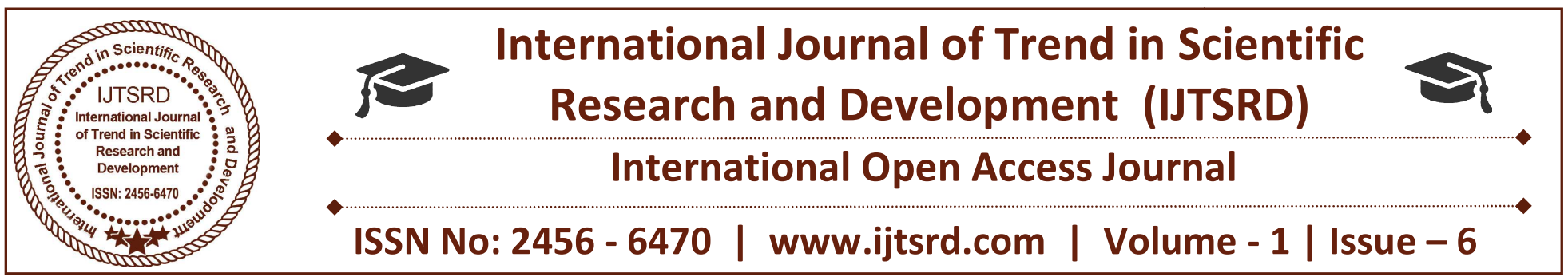

\title{
Financial Health of Food Processing Industry in Tinsukia District of Assam
}

\author{
Mukunda Madhab Gogoi \\ Assistant Professor of Economics, Digboi College
}

\section{ABSTRACT}

Food processing industry transforms raw food stuff or semi finished food into a convenient form for the use of end users. This industry is linked with the activities of agriculture, horticulture, plantation, dairy, animal husbandry and fisheries. Development of food processing industry minimises wastage of agricultural raw materials, increases the value of agricultural products and ensures better prices to farmers as well as affordable prices to consumers. The researcher has made an attempt to access financial analysis of the food processing industry of the district. The financial analysis of the food processing industrial units is attempted to make through liquidity measurement, solvency measurement, profitability measurement and break even analysis. The infrastructural problem, existence of large number of unskilled workers, absence of wider market, frequent strikes, improper banking provisions, absence of government supports are found as the major hurdles in the development of food processing units in Tinsukia district. Though the food processing industrial units are contributing a lot towards the district economy as well as state economy, the policy makers and the governmental officers are seen to neglect their role and contribution. There is a need to transform the outlook of young generation of the district

Keywords: financial analysis; liquidity; solvency; profitability; breakeven analysis

\section{INTRODUCTION}

The Ministry of food processing industries, India defines that food processing industries cover two processes -one manufactured process in which raw product of agriculture, animal husbandry or fisheries is transformed to make commercial edible product and the other is value-added process over food products. The food processing industry is one of the largest industries in India and it is ranked fifth in terms of production, consumption, export and expected growth. The importance of food processing has been increased tremendously in recent years. Development of food processing industries minimises waste of agricultural raw materials, increases the value of agricultural products ensures better prices to farmers as well as affordable prices to consumers.

Though India is agricultural based economy since long and her base in agriculture is reasonably strong at present, still wastage of agricultural produce is sizeable. India's $2 \%$ processing in fruits and vegetables, $35 \%$ in milk, $21 \%$ in meat and $6 \%$ in poultry products are far low comparing to $40 \%$ of processing of agriculture produce in China, 30\% in Thailand, $70 \%$ in Brazil, $78 \%$ in the Philippines and $80 \%$ in Malaysia in general.

\section{OBJECTIVES OF THE STUDY}

a) To examine the financial statement of the food processing industries of the study area.

b) To identify the problems of the food processing industry and suggest corrective measures for improvement 


\section{RESEARCH METHODOLOGY}

There are four category of food processing industrial units (though as per the Ministry of food processing India, Annual reports, 2004 there are six segments of the entire food processing industries in India) in Tinsukia district of Assam. Out of 260 nos of registered food processing industrial units as per the as per the information of DIC, Tinsukia , $20 \%$ of total registered units under each category are selected and 55 units is chosen randomly to make the sample for the study. Comprehensive interview- schedule is prepared and primary data are collected from the entrepreneurs of sample food processing industrial units of Tinsukia district.

The secondary data useful for the study have been collected from the published and unpublished sources through -i) Annual reports and statements ,ii) Books, journals, periodicals and reports, iii) $\mathrm{Ph}$. D. theses etc.(iv) various website.

A. Key Indicators : To make financial analysis of the food processing units of the district, the following financial ratio are used. To make

a) liquidity measurement - current ratio

b) Solvency measurement- Debt to Total Capital Ratio

c) Profitability measurement- Gross profit ratio (GP ratio)

d) Break even analysis - (ratio of Fixed cost to difference between price of output and variable cost)

e) Margin of safety (the current sales are subtracted from the breakeven point, and then result obtained is divided by sales) are applied.

\section{FINDINGS}

A. Liquidity: Liquidity measurement analyses the short term financial position and examines whether an industrial unit is capable of paying short term or current obligations. Here Current Ratio is used to analyse the liquidity position of the food processing industries.

Current ratio: The current ratio analysis of sample food processing industrial

\section{Table No:-1}

Title: Category wise current ratio of the sample food processing units

\begin{tabular}{|l|l|l|l|}
\hline \multicolumn{1}{|c|}{ Category } & $\begin{array}{c}\text { Current } \\
\text { Assets }\end{array}$ & \multicolumn{1}{|c|}{$\begin{array}{c}\text { Current } \\
\text { Liabilities }\end{array}$} & $\begin{array}{c}\text { Current } \\
\text { ratio }\end{array}$ \\
\hline Diary & 355000 & 110100 & $\mathbf{3 . 2}: \mathbf{1}$ \\
\hline $\begin{array}{l}\text { Fruits \& } \\
\text { Vegetables }\end{array}$ & 212000 & 111500 & $\mathbf{1 . 9 : 1}$ \\
\hline $\begin{array}{l}\text { Grains and } \\
\text { cereals }\end{array}$ & 440000 & 157900 & $\mathbf{2 . 7 : 1}$ \\
\hline $\begin{array}{l}\text { consumer } \\
\text { food }\end{array}$ & 406000 & 189400 & $\mathbf{2 . 1 : 1}$ \\
\hline \begin{tabular}{l} 
Average \\
\hline
\end{tabular} & $\mathbf{3 5 3 2 5 0}$ & $\mathbf{1 4 2 2 2 5}$ & $\mathbf{2 . 4 : 1}$ \\
\hline
\end{tabular}

Source: Field Survey

Analysis shows that except fruits and vegetable processing units, all the units are able to pay off their short term liability in a better way as their current ratios are higher than the ideal ratio of 2.1. The fruits and vegetable processing units have heavier current liability comparing to their current assets.

B. Long term solvency: Analysis of long term solvency of a unit examines its power to repay long term liabilities by long term assets._An ideal ratio for debt to total capital ratio is less than $1: 2$ or less than 50 per cent. The category wise debt to total capital ratio for food processing units of the district is shown below. 
Table No:-2

Title: Category wise debt to total capital ratio of the sample food processing units

\begin{tabular}{|l|l|l|l|}
\hline Category & $\begin{array}{l}\text { Long } \\
\text { term debt }\end{array}$ & $\begin{array}{l}\text { Capital } \\
\text { employed }\end{array}$ & $\begin{array}{l}\text { Debt to } \\
\text { total } \\
\text { capital } \\
\text { ratio }\end{array}$ \\
\hline $\begin{array}{l}\text { Druary } \\
\text { Vegetables }\end{array}$ & 458000 & 950000 & $48.2 \%$ \\
\hline $\begin{array}{l}\text { Grains and } \\
\text { cereals }\end{array}$ & 14120000 & 35894000 & $39.3 \%$ \\
\hline $\begin{array}{l}\text { Consumer } \\
\text { food }\end{array}$ & 1100000 & 1920000 & $57.2 \%$ \\
\hline Average & 4089500 & 10153500 & $40.2 \%$ \\
\hline Sources: Field & & & \\
\hline
\end{tabular}

Except the consumer food processing units, all the other categories of units are in a good position in case of debt to total capital ratio. The debt to total capital ratios of all the food processing units are less than $1: 2$ or 50 percent excluding the consumer food processing units of Tinsukia district.

C. Profitability measurement: The analysis of profitability provides the information regarding the capacity of earning profits from its sale. Gross to profit ratio is used to analyse profitability of the food processing units under the study.

Gross profit ratio: Higher is the gross profit ratio, greater is the level of capability of earning profits by an industrial unit. Gross profit is calculated by subtracting cost of goods sold from the The following table shows the gross profit ratio of different categories of food processing units of Tinsukia district.

Sources: Field survey

Table No:-3

Title: Category wise gross profit ratio of the sample food processing units

\begin{tabular}{|l|c|c|c|c|}
\hline Category & Total sale & Cost of goods sold & Gross profit & Gross profit ratio \\
\hline Diary & 900000 & 680000 & 220000 & 0.258 or $25.8 \%$ \\
\hline Fruits \& Vegetables & 309000 & 150080 & 158920 & 0.529 or $52.9 \%$ \\
\hline Grains and cereals & 2400500 & 1362000 & 1038500 & 0.434 or $43.4 \%$ \\
\hline Consumer food & 908500 & 546000 & 362500 & 0.402 or $40.2 \%$ \\
\hline Average & 1129500 & 684520 & 444980 & 0.405 or $40.5 \%$ \\
\hline
\end{tabular}

Source: Field Survey

The above table indicates the fact that the gross profit ratio of fruits and vegetables processing industrial units is the highest and that of diary processing units lowest. $52.9 \%$ ratio of fruits and vegetables processing units implies that this category of units may reduce its selling price by $52.9 \%$ without incurring any losses. Thus the fruits and vegetables processing units are at position to earn greater profits comparing to other categories of units.
D. Breakeven analysis: The breakeven analysis is a very important tool while making selling strategies or making pricing decision. Here the breakeven point of units under a category is calculated by dividing average fixed cost to its average contribution, i.e., difference between average selling price and average variable cost. The breakeven points of units under different categories of food processing units of Tinsukia district are given below. 
Table No:-4

Title: Category wise break even analysis of the sample food processing units

\begin{tabular}{|c|c|c|c|c|c|c|}
\hline Category & $\begin{array}{l}\text { Average } \\
\text { selling } \\
\text { price (Rs) }\end{array}$ & $\begin{array}{c}\text { Average } \\
\text { Variable cost } \\
\text { (Rs) }\end{array}$ & $\begin{array}{c}\text { Average } \\
\text { contribution } \\
\text { (Rs) }\end{array}$ & $\begin{array}{l}\text { Average } \\
\text { monthly } \\
\text { Fixed cost } \\
\text { (Rs) }\end{array}$ & $\begin{array}{l}\text { Average } \\
\text { monthly } \\
\text { breakeven } \\
\text { point(in Units) }\end{array}$ & $\begin{array}{c}\text { Average } \\
\text { monthly } \\
\text { breakeven } \\
\text { sales } \\
\text { value(Rs) }\end{array}$ \\
\hline Diary & 20 & 15 & 5 & 3500 & 700 & 14000 \\
\hline $\begin{array}{ll}\text { Fruits } & \& \\
\text { Vegetables } & \end{array}$ & 40 & 22 & 18 & 3000 & 166.6 & 6664 \\
\hline $\begin{array}{l}\text { Grains and } \\
\text { cereals }\end{array}$ & 2010 & 1360 & 650 & 12200 & 18.7 & 37587 \\
\hline Consumer food & 50 & 29 & 21 & 5500 & 261.9 & 13095 \\
\hline Average & 530 & 356.6 & 173.4 & 6050 & 286.8 & 17836.5 \\
\hline
\end{tabular}

Source: Field survey

The table given above indicates that the breakeven sales value is different among different category of food processing units. The breakeven sale value of fruits and vegetables processing is lowest (Rs 6664) and that of grains and cereal processing units is highest (Rs 37587) among the different categories of units in the district. The breakeven sale of grains and cereal processing units is higher than the district average breakeven sale (Rs 17836.50) and those of dairy, fruits and consumer processing units are lower than the average district breakeven sale.

\section{E. Margin of safety:}

Margin of safety is simply the difference between current sale and the breakeven sale. Margin of safety can also be expressed as ratio by dividing the margin of safety to current sale and multiply the result by 100. The margin of safety is used to inspect the effect on profit or loss with the changes of sales. Larger margin of safety of a unit implies that that unit is better protected from sales variations comparing to smaller ones. The following table shows that the margin of safety ratios of diary, grains and cereals and consumer food.

Table No:-5 Title: Category wise margin of safety ratio of the sample food processing units

\begin{tabular}{|l|c|c|c|c|}
\hline \multirow{2}{*}{ Category } & $\begin{array}{c}\text { Monthly } \\
\text { Current sale } \\
(\mathrm{Rs})\end{array}$ & $\begin{array}{c}\text { Monthly BEP } \\
\text { sales value } \\
(\mathrm{Rs})\end{array}$ & $\begin{array}{c}\text { Average margin } \\
\text { of safety } \\
(\mathrm{Rs})\end{array}$ & $\begin{array}{c}\text { margin of safety } \\
\text { ratio }\end{array}$ \\
\hline Diary & 75000.0 & 14000 & 61000 & 81.3 \\
\hline Fruits \& Vegetables & 25750.0 & 6664 & 19086 & 74.1 \\
\hline Grains and cereals & 200041.6 & 37587 & 162454.6 & 81.2 \\
\hline Consumer food & 75708.3 & 13095 & 62613.3 & 82.7 \\
\hline Average & 94124.9 & 17836.5 & 76288.4 & 79.8 \\
\hline
\end{tabular}

Source: Field Survey 
processing units of Tinsukia district are more or less equal to the average margin of safety ratio of district food processing units(79.8\%). Only the margin of safety ratio of fruits and vegetable processing units is lower $(74.1 \%)$ than that of average margin of safety ratio to some extent.

\section{MAJOR PROBLEMS OF THE FOOD PROCESSING INDUSTRIAL UNITS:}

a) The highest number of food processing units(44.4 percent) in Tinsukia sub-division gave production problem, the highest number of units (52.9 per cent)in Sadiya gave financial problem and the highest number of units $(0.40 \%)$ in Margherita sub-division gave production problem as their first ranked problem.

b) The marketing problem is identified as second ranked problem by the highest number of food processing units(48.2 percent) in Tinsukia subdivision, the production problem is identified as the second ranked problem by the highest number of units (41.2 per cent)in Sadiya and production problem and marketing problem are given second ranked problem by the highest two groups of units $(0.40 \%$ of each $)$ in Margherita sub-division.

c) The third ranked problem is identified as marketing problem by the highest number of units (29.7 percent) in Tinsukia sub-division, production problem and marketing problem by two group of large units (35.3 per cent of each) in Sadiya sub-division and financial problem by the largest number of units (40 percent) in Margherita subdivision.

d) $\quad 90.7$ percent of units get no supports from the government in any form in the district. Only 17.6 percent of units get supports form banks and other financial institutions and except 1.9 percent of units NGOs are not supporting the food processing units of Tinsukia district.

\section{SUGGESTIONS}

On the basis of above findings, the following suggestions are put forwarded for the development of food processing units of Tinsukia district.

a) The complexity and inaccessibility of the banking credit system for the entrepreneurs should be removed. They should be introduced about the latest government industrial policy and the various schemes open for them.

b) There should be separate ministry for food processing industry in the state of Assam as observed in the central government so that proper programmes and projects for the benefits of food processing industrial units can be undertaken.

c) Proper infrastructural facilities in all forms should be developed as far as possible. Particularly in greater part of Sadiya and in some parts of Margherita, the infrastructural provisions for the growth of any type of industrial unit are very poor comparing to Tinsukia sub-division.

d) The NGOs operating in the district should be motivated to take a positive step for the growth and development of food processing units.

\section{Conclusion:}

Though Tinsukia is the topmost commercial and industrial centre of in the entire upper Assam, the performance of food processing units from different angles are not fully satisfactory. The infrastructural problem, existence of large number of unskilled workers, absence of wider market, frequent strikes, improper banking provisions, absence of government supports are some of the major hurdles in the development of food processing units in Tinsukia district. There is a need to transform the outlook of young generation of the district to challenge their traditional job seeking motive. They should be motivated to take the responsibility of job providers instead of job seekers. Thus entrepreneurial developmental schemes should be introduced to a greater extent in different parts of the district from the government side. With the growth of level of living standard and with the increase in income level of common people, there enlarges a market where consumers are attracted to purchase processed and quality foods. Again, as in Tinsukia both agriculture and industry are at a good position; there is a huge potentiality to develop the food processing units and thereby to contribute a lot to the district as well as state economy. Thus, it is the responsibility of not only the government officials but also so the responsibility of the people in general to transform the 
challenges and hurdles into opportunity for the [4] G.S. Mehta, "Agro-processing industry in Uttar realisation of bright future prospects of food processing units of Tinsukia district.

\section{REFERENCES:}

Pradesh: Emerging Structure and Development Potentials", December 15, 2012

[5] T.M. Schmit, K. S. , Park, B. M. Henehan and J. Hall "A Study of Food and Beverage Manufacturing in New [1] V.M Anjana, and Dr. Sr. K.D. Rosa "Food Processing Industrial units In India: An Overview", Facts for You, January 2014, pp. 9- 11

[2] B. Bhattacharyya, "Problems and Prospects of Fruits and Vegetables Processing Industry: A Study in Kamrup District of Assam", Asian Resonance, Vol.-II, Issue-iv, October-2013, pp.38-44

[3] Dr. K. Majumdar, "Need of FDI in Indian Processed Food Sector", International Journal of Marketing and Technology, IJMT, June, 2012, Volume 2, Issue 6, pp.150157 